\title{
OLD AND NEW PROBLEMS IN THE BALKANS AND MARXISM
}

Keywords:

Capitalism; Balkans; Marxism; old and new problems; socialists; transformation of the problems.

Author:

Dr. Mustafa Türkeş is a Professor of International relations from the Department of International Relations of the Middle East Technical University, Ankara, Turkey.

Correspondence:

turkes@metu.edu.tr

Field:

International relations

\section{Summary}

Efforts to determine the place of Marxism in the Balkans in a historical manner seem to enable us to outline not only the historical importance of Marxism but also to point out more precisely its relevance with contemporary problems and possible solutions in the Balkans. In order to outline very briefly the place of Marxism in the Balkans, this paper first seeks to discuss the old (late 19th, early 20th) and new (late 20th, early 21st century) common problems people in the Balkans encountered with a view to underlining the continuity of the problems. Second, it illustrates the way in which the old and new problems had been addressed. I assume that capitalism keeps failing to find a workable solution to any major problem people in the Balkans faced, but constantly transforms the problems with which it overcomes its own survival. Third the paper examines achievements and shortcomings of first and second generation of socialists in the Balkans. Finally, the paper puts forward that it is up to the third generation of Marxist-inspired thinkers to propose an alternative system inspired from Marxism(s) as opposed to the capitalist system that kept failing to address the problem, but transforms the problem itself rather than solving any.

DOI:

10.5937/politeia0-19921

Paper received on:

06.11.2018.

Paper accepted for publishing on:

16.12.2018. 


\section{INTRODUCTION}

Despite the richness of the Balkans' history and complication of its politics, I should underline that the case of the Balkans is not a sui generis one. Its history and politics resemble in many ways those of the Western and Eastern examples because societies in the Balkans have not been immune to the ideas and practices spreading around the world.

The Balkans are presented by mainstream literature as if being a 'powder keg' and put forward as if the major wars, particularly World War I, were 'started because of the Balkan nationalism'. In fact, such comprehensions could not be just treated as misunderstandings but they seem to effectively divert the reality: the nationalisms in the Balkans were rather a symptom not a cause since both world wars were consequences of rivalry among great centres of capitalist imperialism. The mainstream historiographies in the Balkans are products of local and national appraisal of nationalist and religious institutions. One presents the immediate neighborhood as the immediate threat to its survival, and hence next door nationalities are potentially seen as adversary, but in actual fact the real threat comes out of conflicting interests of rival imperialist powers.

The first generation of socialists failed to understand what exactly the immediate threat was and the nature of the imperialist rivalries over the region. Though the Ottoman Empire had never been a full colony of western capitalism, its incorporation in the capitalist system in the $19^{\text {th }}$ century was a fact that also affected its Balkan provinces. The first generation of Socialists only looked at narrow ethnic/cultural and national aspects rather than materialist analysis of the incorporation of the Ottoman Empire in the capitalist system. Many scholars agree that the Ottoman economy, particularly port cities in the first place had been integrated in the capitalist system through trades and some Western capital's direct investment for instance in cotton production in Egypt, Cilicia/Çukurova, or trade routes like Alexandria, Salonica, İzmir and Trabzon. Some places like central Anatolia or some parts of the Balkans were left to decay as no investment took place until it was required. The Tanzimat reformers responded with a rather defensive modernisation that was not accepted by Muslim and Christian communities of the Ottoman Empire. The Tanzimat reforms, which were linked with privileges extended to Western merchants such as the Anglo-Ottoman Trade Agreement of 1838, had a tremendous impact on the destruction of local artisanal production, both in the Balkans and Anatolia. The restructuring of production relations and social relations in the Ottoman Empire was done in most cases by the bureaucratic elite in consultation with European traders' representatives or via diplomatic envoys. Tanzimat reformers who had been influenced by the notions of the French revolution hoped that such reforms would catch-up with their Western counterparts. The defensive reforms failed to deliver the result that they had expected to do so.

Early socialists in the Balkans, for instance, Svetozar Marković, who represented the best of the first generation of Socialists, looked at the whole issue from a national and even more narrowly, only Serbian lens, and sometimes looked down for instance at other religious belief systems as distortion among South-Slavic people. (Lapcevich, 2015). Marković saw both 
the Ottomans and Austrians as the major immediate threats while relying on other competitors in the region as liberators who were indeed actual competitors. As shown below, Marx and Engels read the late $19^{\text {th }}$ century history as a geopolitical competition among all the rival powers, particularly among Britain, Russia and Austria. Whereas the second generation understood well, however, that they were not successful to overcome this issue. Here I have to warn that one cannot really understand the problem of great power rivalries without linking it to the reproduction of capitalist relations of production. For the time being, it is appropriate to say that the mainstream historiographies in the Balkans are as problematic as the non-Balkan mainstream historiographies. Similarly, the first generation of Socialists in the Balkans created a socialist historiography that was read largely from a narrow national lens.

In this paper, my major objective is to show the relevance between the old and new problems in the Balkans. To do so, the paper, in the first place, seeks to outline and discuss the old (early $20^{\text {th }}$ ) and new (very late $20^{\text {th }}$ and very early $21^{\text {st }}$ century) common problems that people in the Balkans encountered with a view to underlining the continuity of the problems. In between these time spans there was a real socialism, which I am inclined to call socialism with national characteristics, the period that nowadays is perceived by some as nostalgic. (Horvat, Štiks, 2015: 195-212).

I assume that capitalism kept and keeps failing to find a workable solution to any major problems that people in the Balkans faced, but constantly transforms the problems with which it overcomes its own crises. Marxist-inspired solutions on the other hand seem to be the only solution that can prepare a ground to emancipate the minds of people from their ethnic and religious oriented thinking as it focuses on class relations that cross-cut ethnic and religious identities. Hence this paper puts forward that an alternative system, inspired from Marxism(s), could provide a better understanding of the old problems while furnishing emancipatory and viable solutions for new ones.

\section{THE MAINSTREAM CIVILISATION APPROACH AND ITS PROBLEMS}

The mainstream civilisational approach locates ethnic and/or national identity, religion and culture at its centre and argues that civilisation can play both dividing and unifying roles among different societies (Wachtel, 2008). According to this approach, more specifically, the Balkans are defined in both ways as a 'borderland' between different civilisations and cultures like Christianity and Islam; between Eastern Orthodoxy and Western Catholicism. In such a framework, the Balkan Peninsula is also considered as a 'melting pot' where all these different civilisations and cultures have lived together. Not surprisingly, the civilisational approach rests on the multiplicity of cultures, which in turn involves divisions among them as well.

The civilisational approach does not offer any specific solutions to actual conflictual situations rather than arguing that there were times in history that people lived together in the Balkans as a melting pot of civilisations. However, not all approaches are that naïve. The conservative mainstream approach as articulated by Huntington's clash of civilisation theory (Huntington, 1993). for example, blames the cultural differences as the cause of all 
problems that exist in the Balkans. In a similar fashion the "Balkan Ghost" (Kaplan, 1993), functioned in the same way suggesting that something is wrong with the societies living in the Balkans. In this respect, it could be argued that instead of providing viable solutions to the problems of Balkans emanating from its multi-ethnic and multi-religious identities, the arguments of both conservative and liberal civilisational approaches do contribute to the consolidation of those identities and the problems accompanied, in most cases imaginarily attributed to them. The only solution that this approach offers is democracy as a panacea for all the problems. Yet democracy could only be part of the solution as keeping the relations among different identities as manageable. However, the solution could not be reduced to the management of identities, it should be about transcending those identities without oppressing them.

The recent history seems to demonstrate that democracy, which both the conservative and liberal wings of the mainstream approaches promised and promoted, failed to deliver what it had promised. The leading liberal scholars who published a series of articles in the Journal of Democracy, ${ }^{1}$ from 2015 onwards, also accepted this reality. However, their emphasis is different from Marxists' concerns.

\section{THE OLD AND NEW PROBLEMS}

Now let's turn to identify and discuss the old and new problems in the Balkans. This enables us to trace the continuities and changes of the problems in the Balkans.

For the sake of brevity and clarity I will limit the time span with the early $20^{\text {th }}$

1 See, Journal of Democracy; https://www.journalofdemocracy.org/ century, though the problems may go as far back as the $19^{\text {th }}$ century and even before. There were six sets of old problems that people in the Balkans commonly faced.

\section{THE OLD PROBLEMS IN THE EARLY 20TH CENTURY}

1. The international recognition of independence and the domestic legitimisation of regimes in the Balkans.

2. Territorial disputes and minority problems.

3. Seeking patronages from one or more extra regional powers to help survive.

4. Dependence on foreign capital and credits.

5. Intra and inter-regional integration tendencies.

6. Establishment of fascist and/or pro-fascist regimes.

7. Formation of contested historiographies

Almost all of the Balkan nations (with the exception of Macedonians) had gained their independence in the second half of the $19^{\text {th }}$ century, yet the Great War had considerable geopolitical impacts on those Balkan countries. Some were satisfied with the stipulation of post-World War I territorial settlements, while others worked for revision of the territories and not surprisingly territorial disputes never ended. (Türkeş, 1994: 123-144) Each relied on a national historiography that glorified a short history of the largest success story in their histories as the basis for future greater national unity. Each asserted that their minorities suffered under neighbouring foreign rule, while denying even the existence of other nations' minorities in their own national states. None of the governments in power in the Balkans were really interested in the Socialist version of the national-self-determination principle as 
they were totally against Socialism of any kind (except for a short period in Hungary). Some engaged with Wilson's national self-determination principle that indeed played a rather fragmentary role. Their domestic legitimisation was done through both external and domestic adversaries. Constitutional monarchies established in the 1920s opened up an avenue for multi-party regimes and elections, though in the 1930s almost all turned into little dictatorships, at best being technocratic governments. In many of them several coup d'états took place. Monarchies did not tolerate republics (the only exception was Turkey) and in one case, in Albania, the republic was turned into a kingdom.

During the inter-war years, each Balkan regime relied on the patronage of one or more extra regional actors, however this did not prevent the Balkans becoming a battleground in World War II. Nor did it lead to a sustainable security system. The French-sponsored Little Entente did not result in more security except contributing to contain Germany, though it failed after Hitler came to power. The Four Power Pact of 1934 did exclude the Balkans from the decision making process and thus alarmed the Balkan countries. The only genuine regional initiative was the Balkan Pact of 1934 that limited itself to prevent Bulgaria together with Italy attacking a Balkan state. In that sense it played some role, however, it failed to play any role regarding the extra-Balkan powers intervention and attack on the Balkans. In short, the efforts for the intra-regional and inter-regional integration of the Balkans resulted in no success.

Each Balkan country sought for industrialisation in the interwar years, however, they lacked the necessary capital to invest in industries. They looked for fresh capital but in vain. Britain, France and the US refrained from providing fresh credits and insisted that unless the Balkan states signed free trade agreements with them they would not be provided fresh credit. Despite the decline in France and Britain's powers, the United States was not yet ready to invest in the Balkans. As a result, it was Germany by the end of 1930s that became the main trade partner in almost all Balkan countries (the only exception being Greece) as they offered clearing agreements to each Balkan state. The result was that not only did they become dependent on Germany but also pro-Nazis became powerful enough to exert their influence in the government and bureaucratic circles in military and political terms as their armies were modernised by the German arms industry. It is not a coincidence that pro-Nazis grew stronger day by day and they joined the war on the side of Hitler. There were three exceptions: Turkey, Greece and Yugoslavia. Turkey opted for active neutrality, Greece was under the influence and patronage of Britain, however, that failed to keep Greece being attacked by Italians and then the Nazi occupation. Yugoslavia was forced by the British to take on their side and thus encouraged the air force to carry a coup d'état in 1940, which resulted in a Nazi attack. The Ustashi, the Croation militia, initially backed by the Vatican and then Nazi Germany, came to power in Croatia and a civil war between two extreme nationalists the Ustashi and the Chetniks, the Serbian militia, occurred. Islamists either kept silent or gave support to German Nazis. Occupation of Yugoslavia by the Nazi forces in turn led to a fully-fledged war and resistance that took place between Tito's Partisans and Nazi invaders. This was a turning point for the second generation of Socialists in Yugoslavia. 
It may be concluded that in the early $20^{\text {th }}$ century liberal proposals failed to deliver a workable international and regional order that gave its place to fascism, which necessarily affected the Balkans.

A real departure occurred following World War II. In most cases the leadership of resistances throughout the Balkans took over the power mainly because they were well-organised political actors and they faced no legitimacy problem, while right wing parties and groups discredited themselves as some had collaborated with Nazis or Fascists.

Two clear patterns emerged: one was that Socialists came to power through native resistance as in the cases of Yugoslavia and Albania, while in another way Socialists in Bulgaria and Romania rose to power as a result of direct support from the Soviet Union. In the final analysis, Socialism with national characteristics was established throughout the Balkans. They were a dictatorship, however, it is debatable as to whether they established a dictatorship of proletariat or a personal one. Each Socialism with a national characteristic nevertheless achieved a modernisation of semi-feudal societies in the Balkans and helped accelerate the urbanisation of the Balkans.

Each had different causes for the regime change that took place starting from November-December 1989 to 1991 in the Balkans. This resulted in a new set of problems: some resemble the old ones, while some were new. It is worthy to examine them, at least to indicate continuities and changes in relation to those new problems.

\section{THE NEW PROBLEMS IN THE LATE 20TH AND EARLY 21ST CENTURY}

In the late $20^{\text {th }}$ and early $21^{\text {st }}$ century there appeared six sets of problems:

1. Formation and new historiographies.

2. Regime changes and the contained wars.

3. Dependence on foreign capital and credits.

4. External and domestic integration tendencies.

5. Dependence on the US, the EU and the Russian Federation.

6. Consolidation of neo-liberalism and the financial and economic crises.

7. Democracy and rise of authoritarianism.

It may be claimed that there is a clear resemblance between the problems that had emerged after the First World War and those that re-emerged in the post-Cold War era. Moreover, all the prescriptions devised out of the liberal toolbox failed to deliver their promises of prosperity, democracy and the rule of law.

Following the regime change, those who came to power in the Balkans were advised to give up their planned and/or worker self-management economies in favour of the free market economy. They were forced to opt for either shock therapy or a gradual change to the market economy and hence they were obliged to carry out privatisation. They all did, though some opted for gradualism, while some opted for shock therapy. The net result was the rapid rise of unemployment and income fell sharply under the poverty line (Lavigne, 2000: 33). Unemployment among the young generation, between the age of 18-24 was even alarming as noted in the statistics of Eurostat databases. ${ }^{2}$ Needless to say, this economic transformation

2 See Eurostat Database, https://ec.europa.eu/eurostat/data/database 
and massive privatisations brought an opportunity for some to make a huge profit and take over state-owned enterprises. This was a kind of jungle capitalism in which the rule of law was not observed well. Property soon changed hands and those who had contacts because of their former posts with western capital owners captured the wealth and helped to concentrate it in the hands of a few, now called oligarchs.

The second piece of advice given to all was that they should abandon single party rule in favour of a multi-party regime. They did so, setting up hundreds of new parties. General elections took place, even more than necessary because no one dared to take up the responsibility of privatization costs, therefore almost every two years, there were new general elections as the governments fell after each privatisation. The EU promised that they should be accepted to the EU if they met the criteria that had been determined together with the International Financial Institutions (IFIs). A smooth transition was supposed to take place according to liberals, particularly the transitologists who specifically studied the transition in the Balkans and Eastern Europe (earlier in Latin America) in general. ( Holmes, 1997: 23:62; Christopher, Mokrzycki, 1994: 15-30; Schopflin, 1993; Türkeş, 2004: 13-28)

If there was a failure the IFIs readily blamed national and local actors. So did mainstream literature, particularly the liberal wing. Mainstream literature indicates that the failure resulted from the process of implementation, which was local or national, but not at the capitalism institutions.

They never questioned their own approach. I argue that this approach is problematic and in fact this is to blame the victims in the Balkans. The reality is that the actual outcome, the failure, is the common responsibility of the IFIs, the EU's policy makers, and in general those who adopted the neo-liberal policies to be implemented in the Balkans. Neo-liberalism was hastily implemented by the national actors in the Balkans as to achieve transition, and therefore they share the responsibility too.

Who is to blame for the rise of authoritarianism?

Mainstream literature and the liberals in particular blamed the remnants of old communists for the rise of authoritarianism and illiberalism for all kinds of failures. ${ }^{3}$

This is a wrong analysis. First of all, communists had lost the power, even beyond this, most of them, the remnants of communists, underwent a transformation to engage with capitalism and the new regime, therefore, it is fair to say that even if they wished to do so, they did not have the power to create hindrances.

The reality is that the policy of IFIs and liberals resulted in the rise of authoritarianism. How did it take place?

From the early 1990s up to the late 1990s IFIs and the liberals assumed that the abandoning of the planned economy in favour of the market economy and the transition from single party rule to multi-party rules through regular elections would produce a democratic society. IFIs, the EU and larger NGOs supported the so-called small, fragmented civil society organisations as to contribute to democratisation. They were encouraged to take the place of mass organisations such as trade unions. However, by the end of 1990s, the IFIs and the advocate of liberals realised that no democratisation has been taking place, and even worse, they could not find reliable actors to deliver

\footnotetext{
3 See the latest issues of liberal journals such as Journal of Democracy https://www.journalofdemocracy.org/ It devoted its July 2018 issue to the decline of democracy.
} 
neo-liberal policies prescribed by the IFIs and the EU in the Balkan countries as they could not remain in power for long and often, there were new elections and new governments, whose future were not so bright in terms of staying in power. It is clear that the transition process proposed by the liberals weakened and in some cases broke the power of a strong state and in view of this process, the IFIs and liberals realised that their policies could not be delivered and implemented by the weak states. This was openly acknowledged by one leading transitologist in an article. ( Holmes, 1997). They could not return to advocate a strong state as they were totally against it, hence they revised their argument in favour of relying on strong political leaderships. The IFIs and the EU started to support strong political leaderships in the Balkans, though this was supposed to be for a short period. However, it appeared to be the case that strong political leaders came to power in the Balkans, with the support of the IFIs and the EU. The IFIs and the EU refrain from acknowledging this. Even so, the IFIs and the EU leaders continue to work with such authoritarian leaders as long as it fits into their overall interests, at least as long as a neoliberal transformation is consolidated in the Balkans. This is the real reason why and how authoritarianism became part and parcel of everyday life throughout the Balkans.

It may be stated that the linkage between the EU's promises, its policy proposals, its implementation and the failure of democratisation indicate that the failure did not result from the process of implementation. Therefore, it is wrong to claim that the problem is local, national and a specific sociological one. The actual outcome, the failure, is the common responsibility of the IFIs and the EU's policy makers who adopted the neo-liberal policies to be implemented in the Balkans and hastily implemented by the national actors in the Balkans as to achieve a transition. Neo-liberalism is being consolidated all over Europe and the Balkans, however democratisation did not take place.

\section{MARXISTS HISTORIOGRAPHIES IN THE BALKANS}

How Marxists read all these is an important question that needs to be tackled as the conference theme is about Marx and Marxism 200 Years On.

Marxism's significance stems from its two tenets; first of all, it offers a materialist conception of history on the basis of production relations and second, it offers an emancipatory approach to culturally diversified wage labourers in the Balkans so that they may produce a social system that is better than the current capitalist-imperialist system.

After the restoration of global capitalism in the Balkans in the 1990s, one can comfortably say, liberal formulas in the post-Yugoslavian space failed to produce regional peace, stability and functioning economies. What accompanied this is a new interest in Marxism(s), which may provide a peaceful and prosperous future for the region. What sort of role Marxism played in the past and what potential it has today needs to be looked into.

Marx and Engels wrote a lot about Western capitalist societies, however less for the peripheries; on India, Russia, China, Algeria, and very little on the Ottoman Empire through some lengthy articles on the Ottoman-Russian Crimean war of 1853. In his book, Marx at the Margins, On Nationalism, Ethnicity and Non-Western Societies, Kevin B. Anderson underlined that 
'Although Marx began to publish in the Tribune in 1851, in that first year all of the articles published under his name were in fact written by Engels. Afterwards, Engels continued to write under Marx's name and for a while some of Marx's German drafts were translated by his friend into English, given his still relatively limited command of the language. For the first two years, their articles focused exclusively on the main countries of Western Europe such as France, Germany, Austria, and Britain, but by 1853 the Russo-Turkish conflict in the Balkans and the Eastern Mediterranean threatened to place this issue, then called the "Eastern Question," at the forefront of European politics. Marx pointed to the growing importance of the Eastern Question, but admitted privately his lack of knowledge of the subject matter, writing to Engels on March 10, 1853: "But this question is primarily military and geographical, hence outside my département. So you must once more exécuter [do it]. What is to become of the Turkish Empire is something I have no clue about. I cannot therefore present a general perspective."' (Anderson, 2012: 13).

Marx and Engels saw the Eastern Question as more of a geopolitical competition. In the analysis of Marx and Engels the Balkans was seen as a place where British, French, Austrian, Russian and Ottoman powers struggled to control this geopolitically significant region. Beyond this, the Balkans did not play much of central role in his analysis of class struggle.

The $19^{\text {th }}$ century was a turning point in the sense that industrial capitalism required incorporation of the Balkans into the capitalist system as to meet its agricultural production needs as well as the market to sell mass industrial commodities. Penetration of capitalist relations led to the transformation of landowning system in the Balkans into more of Çiftlik types, private land owning, and thus, the old Timar system on the basis of state ownership, which did not produce for the market but for a tributary reason, was abandoned in favour of private ownership as the Ottoman Empire became a semi-colonial state from the late $18^{\text {th }}$ century on. In the late $19^{\text {th }}$ century and particularly the early $20^{\text {th }}$ century, Austrian, British and French financial capital penetrated into the Balkans ${ }^{4}$. This change in production relations did not, however, attract much interest by the first generation of Socialists ( $19^{\text {th }}$ and early $20^{\text {th }}$ century). Nor did the second generation (following World War II) devote close attention to it.

During the $19^{\text {th }}$ century, growing local landowners and local traders took up the leadership to revolt against dominant Ottoman rulers. At some places, for instance in Belgrade Pashalık, an interesting picture appeared: the interests of local animal traders and the central authority in the Ottoman Palace, in İstanbul, seemed to overlap as opposed to corrupt Ottoman administrators and military figures, Janissaries in Belgrade Pashalık. This led to a short period of collaboration between the two (Jelavich, 1986, 1987). Following the breakdown of the power of Janissaries and the high bureaucrats in Belgrade Pashalık, who acted independently from the central authority, however, the Ottoman rulers punished both rebel power and the Janissary. On the one hand, the Janissary system was to be

4 See The War Correspondence of Leon Trotsky: The Balkan Wars 1912-13. For Lenin's classic Marxist Theory of Imperialism see, Imperialism: The Highest Stage of Capitalism that appeared in 1916. 
abolished as the Karađorđević leadership in the Belgrade Pashalık weakened it. On the other hand, the Karađorđević dynasty was not given an independence, but a relative autonomy was recognised. The Karađorđević dynasty or later the Obrenović dynasty looked for outside support ranging from Napoleon of France who initially advised them to talk to the Austrians ( Meriage, 1978: 421-439), which was not a good option for the Serbs. However, Serbs later approached the Russian Tsar who was not yet ready to give full military support, though the Tsar readily gave limited political support. The Tsar was balancing between pan-Slavists who encouraged the Tsar to give his full support to the Serbian uprising and what may be called a foreign office department that was cautious with pan-Slavism. Even though the help of Britain prevented its independence from the Ottomans, Serbia was able to gain its autonomy as a consequence of both the uprising and the 1806-1812 war between the Russian and the Ottoman Empires. Internationally recognised independence would come only after the 1877/8 war between the Ottoman and Russian Empires, and recognition of the independence of Serbia, Montenegro and Romania would be materialised and officially recognised at the Berlin Treaty in July 1878, while Bulgaria was divided into two and its independence was to come only after the liberal revolution of 1908.

The peasant rebellion the Karađorđević leadership represented culminated in autonomy, and was a consequence of both foreign support and a power struggle within the power structure of the Ottoman rule. The Ottoman Sultan wanted to break the power of Janissaries and thus turned a blind eye to the rebel powers in Belgrade Pashalık. When Serbs undermined the power of the
Janissaries, only then did the Sultan decide to punish the rebel powers. The Serbian peasant rebellion was a precedent that would be repeated and even became a pattern of continuity in the Greek peasant rebellion in 1821. The Russo-Turkish war of 1828-29 played a major role in helping Greece to obtain its independence. It should be underlined that the European powers, for the first time in the Balkans, imposed a monarchy imported from Bavaria, Otho, and the Greek government who won its independence. This would be repeated in the case of Bulgaria and later in the case of Albania.

In his analysis, Engels referred to the Serbian uprising, summarised geopolitical aspects of it and underlined the significance of the Russo-Turkish war of 1806-1812. According to him, the Russo-Turkish war of 1806-1812 on the one hand helped the Serbian cause but on the other hand gave a free hand to suppress the Serbian rebel by the Ottoman Sultan. In short, in the analysis of Engels (under the name of Marx) the Balkans was a matter of geopolitical issue. (Engels, 1979: 22-27).

The cases we have looked into so far, show the fact that national causes overshadowed the class analysis in the Balkans in the $19^{\text {th }}$ century. If one reads $19^{\text {th }}$ and early $20^{\text {th }}$ century Socialists' writings, he or she can clearly see that their readings of social history rest on national perspectives. That is why class analysis remained neglected or sometimes totally absent.

This is reflected in the first and even second generation of the Socialist thinkers and leaderships in the Balkans. Late $19^{\text {th }}$ and early $20^{\text {th }}$ century Socialists in the Balkans seemed to put emphasis on the exploitative relationships between the external oppressors and the oppressed nation itself. That 
is to say, they declared their own nation as oppressed, while designating the Ottomans or Austrians as the oppressors (Daskalov, Mishkova, 2014), but never questioned both the Turks and Balkan workers' exploitations by the same common rulers. Therefore, they seemed to give priority to the contradictory relationship between the oppressing and oppressed nations. As a result, the idea of a national struggle against external oppressors took precedence over class contradictions. The Ottoman Empire was considered as the state of Turks, who exploited the Balkan peoples. This is one of the fault lines in socialist historiographies in the Balkans that has frequently neglected the fact that the rulers exploited all of their subjects.

The Marxist-inspired analysis in Turkey in the Ottoman Empire were largely inspired through Salonika, where there was a Socialist group who advocated the unity of workers in the Ottoman Empire, and where Balkan socialists were also involved. However, following the Balkan wars of 1912/13, all leftist groups within the Empire took on increasingly national characteristics. The Turkish leftists' groups were no exception, hence they started to question their relations with the Balkan leftist's groups. The Turkish leftist groups became more visible as they opposed to the Allied powers occupation of Istanbul in the 1920s.

There are some similarities between the Turkish and Balkan Socialists in terms of their sources of inspiration: Like the Socialists in the Balkans, some were inspired by the Bolsheviks, as the Communist Party of Turkey was set up following the release of prisoners of war after the Bolsheviks came to power and then formed a political party in Baku during the First Congress of the Peoples of the East, held in the name of the Central Committee of the Communist
International in September 1920 in Baku, Azerbaijan. Others were inspired by leftists' discussions in Berlin, most of whom were students who had gone there to study in early $20^{\text {th }}$ century and been involved in leftists' debates. The Third International played a very significant role in both strands as well as the Turkish and the Balkan cases.

One interesting example among others is Yusuf Akçura's interpretation. Even though he, whose family by origin were a Volga Tatar from the Russian Empire immigrated to İstanbul, was considered as one of the leading figures in the Pan-Turkism movement, his interpretation of the collapse of the Ottoman history is interestingly Marxist-inspired and radically differed from the above mentioned first generation of Socialists in the Balkans. Yusuf Akçura had escaped from the oppression of Abdülhamid II to Egypt and then Paris to study political science, he wrote his famous "Three Way Policies: Ottomanism, Pan-Islamism and Pan-Turkism" that appeared in 1904, and in April 1923 gave a talk in the Ankara branch of Turkish Hearts, entitled "The Economic Roots of Turkish Nationalism”, which was remarkably, a Marxist-inspired analysis. Yusuf Akçura covered five points in his speech:

'First, he clearly said that the Ottoman Empire, like the Hapsburg Empire, was a supra-national one, and belonged to the mediaeval age. Second, he said that the ruling class in the Ottoman Empire had exploited all Ottoman subjects, both Muslims and non-Muslims. Members of the ruling class, he said, had lived a luxurious life by exploiting peasants and war revenues. He added that Armenians, Greeks and Jews had benefitted from imports of luxuries, since they had commercial relations with 
European merchants, and as a result, these non-Muslim merchants, who had controlled foreign, as well as domestic, trade, had generated capital and gained access to the Ottoman ruling circle. $\mathrm{He}$ suggested that the Ottoman ruling class and these merchant groups had been in collaboration in exploiting Muslim and non-Muslim subjects. Third, Akçura asked why the Ottoman Empire had collapsed, and how. In his view, internal and external factors had played a role. Internally, the exploitation of the peasants, in the course of time, became insufficient to meet the luxury expenditures of the ruling class, and in order to meet this deficit, the Ottoman Empire had borrowed loans from European Powers, which in turn had opened the way for European interference in Ottoman finance. In Akçura's view, internal factors were secondary to external global developments in explaining the collapse of the Ottoman Empire: the latter developments included the discoveries of new trade routes, the industrial revolution and the French revolution. From the 17th century onwards, while the military and economic powers of the Ottoman Empire had remained static, the discovery of new trade routes and the industrial revolution had resulted in the economic and military ascendancy of European powers over the Ottoman Empire. The industrial revolution had not only resulted in mass production, at prices lower than those of any artisan production, but also had led to the establishment of big companies and trusts, which had their own banking houses to generate the necessary capital. The traditional Ottoman means of production could not compete with their European counterparts, and this had resulted in the closure of many workshops and factories in the Ottoman Empire. The capitulations granted to European states had further consolidated European ascendancy over Ottoman industry and trade. Fourth, as a result of industrialisation and the huge increase in trade, Akçura said, a new group, the bourgeoisie, had emerged in Europe demanding access to power with the slogan of equality and freedom. This process, he said, had resulted in the replacement of the old aristocracy by the newly emerging bourgeoisie, and the establishment of national states. The ideas of the French revolution had become widespread in Europe and in the Ottoman Empire: non-Muslim subjects in the Balkans had demanded a separation from the Ottoman Empire and the Muslim Arab population had then followed suit. One of the reasons for non-Muslim subjects' demands for separation, Akçura asserted, had been the Ottoman Empire's failure to protect the interests of its Muslim and non-Muslim merchants against European merchants, who were advantaged by the capitulations. This in turn had encouraged non-Muslim subjects of the Ottoman Empire to turn for protection to Russia and the European Powers, further reinforcing their desire for separation from the Ottoman Empire. While the non-Muslim Ottoman subjects had collaborated with the European Powers, the Turks had been left to defend the Ottoman Empire until it had lost the First World War. Fifth, the Turkish War of Liberation, he said, had been the Turks' struggle for the establishment of a Turkish state. This political objective had been accomplished, and from now 
on, every Turk must work for the accomplishment of an economically independent Turkish state. (Türkeş, 1993).

The importance of this talk lay first, in its attempt to offer a socio-economic explanation of the Ottoman Empire's decline, and second, in its insistence that the new Turkish state must achieve economic as well as political independence. Both these points were echoed, in general terms, in speeches of Turkish Socialists in some different wordings.

The $20^{\text {th }}$ century Socialist leaders of the Balkan countries, who were of the second generation, all earned their legitimacies through the war of resistance and liberation during World War II. Most of them remained in power long enough though one died early: in Bulgaria Georgi Dimitrov died in 1949 and Vulko Chervenkov came to power, but was removed from the office in 1954 and replaced by Zhivkov who remained until 1990; in Romania Gheorghiu-Dej died in 1965 and was replaced by Nicolae Ceaușescu, assassinated in 1989; Tito died in 1980, and Hoxha in 1985.

Tito, Hoxha and Dimitrov had been involved in the Third International and thus had theoretically had a Marxist and Leninist background. However, each looked at the issue from a national lens. They proved their leadership during the World War II years and when the war ended they did not face any legitimacy problems in asserting the power in their own countries. This generation of leadership benefitted from Marxism more than the earlier generation. Take for instance Tito, he offered at least two things, one was a solidarity between peoples-nations in the slogan of 'peoples' friendship' that helped bring many diversified national-cultural groups together. It played a unitary role rather than a divisive one. Tito's second promise was the equality between peoples as well as republics in Yugoslavia that differed from the previous Yugoslavia, where such equality had never been thought of. Both promises on the one hand helped bring people together, however on the other hand contributed to the process of consolidation of national differences among six republics and two autonomous provinces. Tito, Ceaușescu, Hoxha all sought for industrialisation and entered into friction with the Soviet leadership for the cause of National issues as well as industrialisation.

Hoxha benefitted from Marxism as to transform a very underdeveloped feudal society divided between tribes, namely Ghegs in the north and Tosks in the south of Albania. He successfully, though forcibly, intermingled the two major tribes into a relatively modernised nation. Dimitrov, together with Tito, advocated the Balkan federation as to create a region where nations lived together, side by side, but failed because both suspected each other of the Macedonian question and feared such a federation might destroy more than bring them together. They were all careful enough to prevent things turning into a national conflict in the Balkans. Balkan socialists loved tension but refrained from open armed confrontation during the Cold War years. Yet, it should be underlined that the second generation of Socialist leadership, like the first one, was not successful enough to prioritise the class analysis.

It may also be suggested that Socialists in the Balkans benefitted from the already existing antagonistic rival system that had started as early as 1917 onwards, though in the course of time it turned into a cause for friction within the Socialist systems as 
a result of mismanagement by the leaderships of Socialist Yugoslavia and the Soviet Union.

Nevertheless, there appeared no actual war between Socialist states in the Balkans until the change of regimes in Eastern Europe. However, as global capitalism restored in the Balkans, geopolitical competition returned with a dreadful consequence.

\section{CONCLUSION}

It may be concluded that Marxism with national characteristics played important roles in the Balkans and it still has the potential to do so. Each Socialism in the Balkans with a national characteristic achieved some sort of modernisation; semi-feudal societies were transformed into more urbanised ones in the Balkans. Back to the past, it is undeniable that the first generation of Socialists contributed to the separation of the Balkans from the Ottoman Empire, however, they failed to take up the whole issue as a matter of integration into the capitalist system, not to mention that they did not take class analysis into account, but bound themselves with a national question. They reduced their struggle against imperialism only to the Ottoman masters, while not realising collaboration with other powers would make them equally dependent. This was a transformation of dependency.

The second generation was more successful in terms of the creation of urbanised, modern, literate and relatively better egalitarian societies as compared to their counterparts in the capitalist system, in the final analysis, however, they failed to overcome local ethnic nationalisms and their socialist project eventually collapsed. To a certain extent they were able to transcend their local, national and even regional differences without much oppressing, however, they all went through some mismanagements.

Given the fact that liberalism of any sorts at world level from the restoration of capitalism in the 1990s to today, especially in the Balkans, failed to provide workable solutions in addressing the problems in the Balkans. Not to mention that no emancipation occurred. It seems it is up to the third generation of Socialist and particularly Marxist thinkers, as to whether they can incorporate a class analysis in their overall approach, this time, promoting solidarity between the wage labourers as opposed to the capital owners at national, regional and global levels.

The succession war in Socialist Federative Yugoslavia in the early 1990s played the most negative role in contributing to the consolidation of the nationalistic and cultural alienation among the working classes for a long time. There are, however, seeds to discern that there is a growing solidarity among wage labourers regardless of their ethnic and/or religious affiliations. Bosnia-Herzegovina is the most significant case to prove that the working class can overcome the difficulties, not the joint venture companies between ethnic/religious based communities the liberals had hoped to be realised but failed at. Therefore, they look for partitioning, that means, a return to old diversity. Working classes of the Balkans have to come together to emancipate themselves. This is the task for the new generation of Marxists whose priority should be solidarity among the working classes. This does not mean that ethnic and cultural affinities can and should be put aside. It must be understood well, that the priority should be on class solidarity. This starts with a better analysis of Marxism, specifically in the Balkans. 


\section{REFERENCES}

Anderson, K. B. (2012). Marx at the Margins, On Nationalism, Ethnicity and Non-Western Societies. Chicago and London:.The University of Chicago Press.

Christopher G. A. Bryant, C., Mokrzycki, E. (1994). The New Great Transition. LondoN: Routledge

Daskalov, R., Mishkova, D. (Ed) (2014). Entangled Histories of the Balkans, Transfers of Political Ideologies and Institutions, 2, Leiden and Boston: Brill.

Engels, F. (1979). The Turkish Question, in Marx and Engels Collected Works, 12, Moscow: Progress Publishers: 22-27.

Eurostat Database, https://ec.europa.eu/ eurostat/data/database

Holmes, L. (1997). Post-Communism, Durham: Duke University Press.

Holmes, L. (1997). The Democratic State or State Democracy? Problems of Post-Communist Transition. Jean Monnet Chair Paper RSC NO 97(48), Florence: European University Institute.

Horvat, S., Štiks, I. (2015). Welcome to the Desert of post-Socialism: Radical Politics after Yugoslavia, London: Verso Books.

Huntington, S. P. (1993). The Clash of Civilizations. Foreign Affairs: Summer.

Jelavich, B. (1986, 1987). History of the Balkans, Volume 1 and 2, Cambridge: Cambridge University Press.
Journal of Democracy; https://www.journalofdemocracy.org/

Kaplan, R. (1993). Balkan Ghosts: A Journey Through History. New York: St. Martin's Press.

Kojanic, O. (2015). Nostalgia as a practice of the self in post-socialist Serbia. Canadian Slavonic Papers, 57(3-4): 195-212.

Lapchevich, S. M. (2015). A Brief History of Serbian Socialism, Part I, translated by Drashkovic, N. and ed. by Flores, J. https:// syncreticstudies.com/2015/08/25/a-briefhistory-of-serbian-socialism-part-i/

Lavigne, M. (2000). Ten Years of Transition: A Review Article. Communist and PostCommunist Studies.

Meriage, L. P. (1978). The First Serbian Uprising (1804-1813) and the Nineteenth-Century Origins of the Eastern Question, Slavic Review, 37(3): 421-439.

Schopflin, G. (1993). Politics in Eastern Europe, Oxford: Blackwell.

Türkeş, M. (1993). Ideological Tendencies in the Republic of Turkey: the Case of Kadro. Ph.D. Thesis. Manchester: University of Manchester.

Türkeş, M. (1994). The Balkan Pact and Its Immediate Implications for the Balkan States. Middle Eastern Studies, 30(1): 123-144. 
Türkeş, M. (2004). The Double Process: Transition and Integration and Its Impact on the Balkans in Towards Non-violence and Dialogue Culture in Southeast Europe, ed. by Mitev, P.E., Riordan, J. Sofia: Iztok-Zapad Publishing House, 13-28.

Wachtel, A. B. (2008). The Balkans in World History. Oxford New York: Oxford University Press. 


\section{СТАРИ И НОВИ ПРОБЛЕМИ НА БАЛКАНУ И МАРКСИЗАМ}

Кључне ријечи:

Капитализам; Балкан; марксизам; стари и нови проблеми; соиијалисти; трансбормација проблема.

Аутор:

Др Мустафа Туркез је професор међународних односа са Одсјека за међународне односе Блискоисточног техничког универзитета из Анкаре, Турска.

Коресподенција: turkes@metu.edu.tr

Област:

Међународни односи

DOI:

10.5937/politeia0-19921

Датум пријема чланка:

06.11.2018.

Датум прихватања чланка за објављивање:

16.12.2018.

\section{Сажетак}

Чини се да нам напори да се одреди улога марксизма на Балкану у историјском смислу омогућавају не само да се истакне юегова историјска важност, већ и да се прецизније упути на юегову важност у погледу проблема савременог Балкана и могућих рјешена. Стога се у раду прво укратко разматрају стари (касни 19. и рани 20. вијек) и нови (касни 20. и рани 21. вијек) општи проблеми народа Балкана, с намјером да се назначи юихов континуитет. Након тога, објашнава се начин на који се прилазило овим проблемима. Аутор претпоставтьа да капитализам нема рјешень за било какве озбиьне проблеме с којима се народи Балкана суочавају, али их успјешно трансформише, чиме си омогућава сопствени опстанак. Дале, у раду се пропитују постигнућа и недостаии прве и друге генерације соиијалиста на Балкану. На крају, истиче се да је на трећој генерацији мислилаца надахнутих Марксовим дјелом да предложе алтернативни систем инспирисан марксизмом и неговим иначииама као супротност капиталистичком систему који не успијева да се избори с наведеним проблемима, већ им само мијеюа облик. 